\title{
Lactobacillus sake Katagiri, Kitahara, and Fukami 1934 Is the Senior Synonym for Lactobacillus bavaricus Stetter and Stetter 1980
}

\author{
ANGELIKA S. KAGERMEIER-CALLAWAY ${ }^{1}$ AND ECKHARD LAUER ${ }^{2 *}$ \\ Poliklinik fuer Zahnerhaltungskunde, D-55101 Mainz, ${ }^{1}$ and Bacteriology Department, \\ Zyma GmbH Betriebsstätte Berlin, D-12057 Berlin, ${ }^{2}$ Germany
}

\begin{abstract}
The taxonomic relationships of six strains of Lactobacillus bavaricus, including type strain 136 (= DSM 20269) and reference strain Tro-8/78, Lactobacillus curvatus, and Lactobacillus sake were assessed by performing DNA-DNA hybridization experiments. We confirmed that $L$. curvatus and $L$. sake are genotypically distinct species. However, the previously described differentiation of $L$. bavaricus from $L$. sake could not be substantiated. We found that $L$. sake is specifically related to the type strain of $L$. bavaricus and all $L$. bavaricus reference strains except " $L$. bavaricus" Tro-8/78, which is related to $L$. curvatus. Clearly, strains identified as $L$. bavaricus Stetter and Stetter 1980 do not form a separate genotypic group, and the name $L$. bavaricus is a junior synonym of $L$. sake Katagiri, Kitahara, and Fukami 1934.
\end{abstract}

Bacterial isolates obtained from sauerkraut or fermented cabbage leaves were described previously as members of the new species Lactobacillus bavaricus (9). This species was differentiated from the phenotypically very similar species Lactobacillus sake and Lactobacillus curvatus because it formed only L-(+)-lactic acid and not the racemic product during growth in cabbage leaf juice. Growth experiments (10) revealed that lactic acid racemase activity apparently is not present in Lactobacillus bavaricus strains, in contrast to Lactobacillus curvatus and Lactobacillus sake strains. The separate species status of Lactobacillus bavaricus was recently substantiated by Champomier et al. (2), but not by other workers (4). In this paper we present evidence that distinction of Lactobacillus bavaricus as a separate species is not justified.

Type and reference strains were obtained from culture collections, as indicated in Table 1 . The isolates used in this study were original subcultures used in the study of Stetter and Stetter (9) or extended studies (11) or were obtained from other sources (7). In addition, two apparently mislabelled strains, Bifidobacterium adolescentis ATCC 11146 and Bifidobacterium bifidum ATCC 11147, which resemble Lactobacillus sake and Lactobacillus curvatus phenotypically, were also examined to determine their true taxonomic relationships. DNADNA hybridization experiments and experiments to determine DNA $\mathrm{G}+\mathrm{C}$ contents were performed as described previously (5).

As shown in Table 1, the overall DNA G $+\mathrm{C}$ contents of the strains belonging to the Lactobacillus sake-Lactobacillus curvatus-Lactobacillus bavaricus group, including the two "Bifidobacterium" strains which we studied, ranged from 41 to 44 mol\%. Thus, the G+C contents of the "Bifidobacterium" strains were clearly outside the range of $\mathrm{G}+\mathrm{C}$ contents of all known Bifidobacterium species (55 to $67 \mathrm{~mol} \%$ ) (8). DNADNA hybridization clearly revealed that both "Bifidobacterium" strains are closely related to Lactobacillus sake (levels of homology, 89 to $98 \%$ ) (Table 1 ).

\footnotetext{
${ }^{*}$ Corresponding author. Mailing address: Bacteriology Department,
} Zyma GmbH Betriebsstätte Berlin, Neukoellnische Allee 146, D-12057 Berlin, Germany.
We performed DNA-DNA reassociation experiments and found that the type strain of Lactobacillus sake, ATCC 15521, and Lactobacillus curvatus reference strain DSM 20010 exhibited about $50 \%$ homology with each other but very low levels of homology (around 10\%) with strains belonging to other species, including Lactobacillus casei DSM $20011^{\mathrm{T}}$ ( $\mathrm{T}=$ type strain), Lactobacillus salivarius DSM 20492, and Lactococcus lactis DSM 20175 (= ATCC 15577). Thus, the separate species status of Lactobacillus sake and Lactobacillus curvatus was confirmed; our results are consistent with the results of Beck et al. (1) and Dellaglio et al. (3).

As shown in Table 1, Lactobacillus sake strains were related at levels of 80 to $100 \%$ to Lactobacillus bavaricus strains, including Lactobacillus bavaricus $136^{\mathrm{T}}$ (= DSM 20269 $)$ and all of the Lactobacillus bavaricus reference strains except strain Tro-8/78, which was closely related to Lactobacillus curvatus instead. Generally, none of the racemase-negative strains, including one isolate obtained from sausage (7), belonged to a separate genotypic group, which could be assigned to Lactobacillus bavaricus.

Therefore, we did not confirm the results of Champomier et al. (2). Since these authors used a different subculture of Lactobacillus bavaricus $136^{\mathrm{T}}$ and a different hybridization method, it will be necessary to repeat their study with Lactobacillus bavaricus DSM $20269^{\mathrm{T}}$.

We concluded that the absence of racemase activity in strains belonging to the Lactobacillus sake-Lactobacillus curvatus group is not a valid criterion for separating taxa. The distinction of Lactobacillus bavaricus from Lactobacillus sake or Lactobacillus curvatus, as proposed by Stetter and Stetter (9), is not justified, and Lactobacillus sake Katagiri, Kitahara, and Fukami 1934 is a senior synonym of Lactobacillus bavaricus.

\section{REFERENCES}

1. Beck, R., N. Weiss, and J. Winter. 1988. Lactobacillus graminis sp. nov., a new species of facultatively heterofermentative lactobacilli surviving at low $\mathrm{pH}$ in grass silage. Syst. Appl. Microbiol. 10:279-283.

2. Champomier, M.-C., M.-C. Montel, F. Grimont, and P. A. D. Grimont. 1987. Genomic identification of meat lactobacilli as Lactobacillus sake. Ann. Inst. Pasteur (Paris) 138:751-758.

3. Dellaglio, F., V. Bottazzi, and M. Vescovo. 1975. Deoxyribonucleic acid homology among Lactobacillus species of the subgenus Streptobacterium 
TABLE 1. Sources, genomic characteristics, and genotypic grouping of the strains which we investigated

\begin{tabular}{|c|c|c|c|c|c|c|c|c|c|c|c|c|c|}
\hline \multirow[b]{2}{*}{$\begin{array}{c}\text { Source of } \\
\text { unlabeled DNA }\end{array}$} & \multirow[b]{2}{*}{ Source $^{a}$} & \multirow[b]{2}{*}{ Reference } & \multirow[b]{2}{*}{$\begin{array}{c}\mathrm{G}+\mathrm{C} \\
\text { content } \\
(\mathrm{mol} \%)\end{array}$} & \multicolumn{10}{|c|}{$\%$ Relative binding with ${ }^{3} \mathrm{H}$-labelled DNA from ${ }^{b}$ : } \\
\hline & & & & 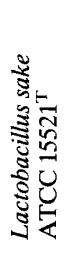 & 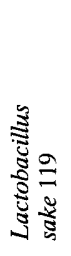 & 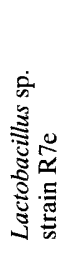 & 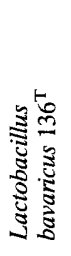 & 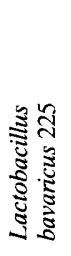 & 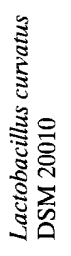 & 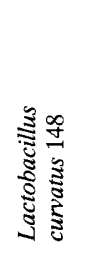 & 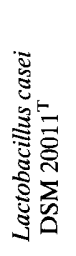 & 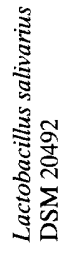 & 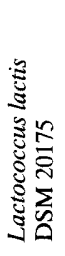 \\
\hline \multicolumn{14}{|l|}{ Lactobacillus sake strains } \\
\hline ATCC $15521^{\mathrm{T}}$ & ATCC & & 41 & 100 & 100 & 100 & 101 & 97 & 53 & $\mathrm{ND}^{c}$ & 9 & 11 & 15 \\
\hline 117 & Sauerkraut & 11 & 42 & 105 & 100 & ND & 100 & 95 & 57 & ND & ND & 10 & 12 \\
\hline 119 & Sauerkraut & 11 & 42 & 96 & 100 & ND & 102 & 90 & 53 & 51 & ND & 11 & 10 \\
\hline $2 / 1$ & Sauerkraut & 11 & 41 & 100 & 100 & ND & 99 & 99 & 60 & ND & ND & 12 & 14 \\
\hline DL 23 & Sauerkraut & 11 & 42 & 100 & ND & ND & ND & ND & 46 & ND & 12 & ND & 7 \\
\hline Tro 11 & $\mathrm{FCL}^{d}$ & 11 & 42 & 100 & ND & ND & ND & ND & 39 & ND & 8 & ND & 7 \\
\hline Lactobacillus sp. strain $\mathrm{R} \mathrm{e}^{e}$ & Sausage & 7 & 43 & 93 & ND & 100 & ND & ND & 36 & ND & ND & ND & 9 \\
\hline \multicolumn{14}{|l|}{ Lactobacillus bavaricus strains } \\
\hline $136^{\mathrm{T}}(=\mathrm{DSM} 20269)^{\mathrm{T} e}$ & Sauerkraut & 9 & 42 & 80 & ND & ND & 100 & 85 & 48 & ND & ND & 11 & 12 \\
\hline $225^{e}$ & Sauerkraut & 11 & 41 & 87 & 87 & ND & 96 & 100 & 51 & ND & 7 & 11 & 8 \\
\hline $\mathrm{L}^{e}{ }^{e}$ & Sauerkraut & 11 & 44 & 83 & ND & ND & ND & 83 & 47 & ND & 8 & ND & 7 \\
\hline $\mathrm{L}^{e}$ & Sauerkraut & 11 & 43 & 92 & ND & ND & ND & 88 & 51 & 46 & 9 & ND & 7 \\
\hline $\mathrm{L} 4^{e}$ & Sauerkraut & 11 & 43 & 100 & ND & ND & ND & 99 & 57 & 54 & 10 & ND & 8 \\
\hline Tro-8/78 & FCL & 9 & 42 & 48 & 48 & ND & 50 & 47 & 100 & 96 & 10 & 9 & 6 \\
\hline $\begin{array}{l}\text { Bifidobacterium adolescentis } \\
\text { ATCC } 11146^{f}\end{array}$ & ATCC & & 43 & 89 & ND & ND & 94 & 85 & 55 & ND & ND & 13 & 14 \\
\hline $\begin{array}{l}\text { Bifidobacterium bifidum } \\
\text { ATCC } 11147^{f}\end{array}$ & ATCC & & 43 & 89 & ND & ND & 98 & 89 & 56 & ND & ND & 14 & 16 \\
\hline \multicolumn{14}{|l|}{ Lactobacillus curvatus strains } \\
\hline DSM $20010^{g}$ & DSM & & 43 & 50 & 50 & 48 & 53 & 52 & 100 & 100 & 12 & 11 & 11 \\
\hline 148 & Sauerkraut & 11 & 44 & 48 & ND & ND & ND & ND & 108 & 100 & 9 & ND & 8 \\
\hline DL 6 & Sauerkraut & 11 & 44 & 51 & ND & ND & ND & 46 & 100 & 100 & 8 & ND & 6 \\
\hline DL 17 & Sauerkraut & 11 & 44 & 52 & ND & ND & ND & 43 & 96 & 100 & 9 & ND & 6 \\
\hline Tro 17 & FCL & 11 & 43 & 42 & ND & ND & ND & ND & 100 & ND & 9 & ND & 7 \\
\hline $\begin{array}{l}\text { Lactobacillus casei DSM } \\
\qquad 20011^{\mathrm{T}}\left(=\text { ATCC } 393^{\mathrm{T}}\right)\end{array}$ & DSM & & 49 & 8 & 8 & ND & ND & 9 & 11 & 6 & 100 & 10 & 3 \\
\hline $\begin{array}{l}\text { Lactobacillus salivarius DSM } \\
\qquad 20492\end{array}$ & DSM & & 33 & 8 & 9 & ND & 8 & 10 & 8 & ND & 10 & 100 & 11 \\
\hline Lactococcus lactis DSM 20175 & DSM & & 38 & 9 & 8 & 9 & 6 & 9 & 9 & 7 & 3 & 7 & 100 \\
\hline
\end{tabular}

${ }^{a}$ ATCC, American Type Culture Collection, Rockville, Md.; DSM, Deutsche Sammlung von Mikroorganismen, Braunschweig, Germany.

${ }^{b}$ As determined by DNA-DNA hybridization.

${ }^{c} \mathrm{ND}$, not determined.

${ }^{d}$ FCL, fermented cabbage leaves.

${ }^{e}$ Lactic acid racemase-negative strain.

${ }^{f}$ Isolated from infant feces and placed in the genus Bifidobacterium by Malyoth and Bauer (6)

${ }^{8}$ The level of DNA-DNA relatedness to type strain DSM 20019 (= ATCC 25601) is 100\% according to Dellaglio et al. (3).

Orla-Jensen. Int. J Syst. Bacteriol 25:160-172.

4. Kandler, O., and N. Weiss. 1986. Section 14. Regular, nonsporing grampositive rods, p. 1226. In P. H. A. Sneath, N. S. Mair, M. E. Sharpe, and J. G. Holt (ed.), Bergey's manual of systematic bacteriology, vol. 2. The Williams \& Wilkins Co., Baltimore.

5. Lauer, E., C. Helming, and O. Kandler. 1980. Heterogeneity of the species Lactobacillus acidophilus (Moro) Hansen and Mocquot as revealed by biochemical characteristics and DNA-DNA hybridisation. Zentralbl. Bakteriol. Parasitenkd. Infektionskr. Hyg. Abt. 1 Orig. Reihe C 1:150-168.

6. Malyoth, G., and A. Bauer. 1950 . Beobachtungen am Bacterium bifidum. Z. Kinderheilkd. 68:358-367.

7. Reuter, G. 1970. Laktobazillen und eng verwandte Mikroorganismen in Fleisch und Fleischerzeugnissen. II. Mitteilung: Die Charakterisierung der isolierten Laktobazillenstämme. Fleischwirtschaft 50:954-962.

8. Scardovi, V. 1986. Section 15. Irregular nonsporing gram-positive rods. Ge- nus Bifidobacterium Orla-Jensen 1924, p. 1418. In P. H. A. Sneath, N. S. Mair, M. E. Sharpe, and J. G. Holt (ed.), Bergey's manual of systematic bacteriology, vol. 2. The Williams \& Wilkins Co., Baltimore.

9. Stetter, H., and K. O. Stetter. 1980. Lactobacillus bavaricus sp. nov., a new species of the subgenus Streptobacterium. Zentralbl. Bakteriol. Parasitenkd. Infektionskr. Hyg. Abt. 1 Orig. Reihe C 1:70-74.

10. Stetter, K. O., and O. Kandler. 1973. Untersuchungen zur Entstehung von DL-Milchsäure bei Lactobacillen und Charakterisierung einer MilchsäureRacemase bei einigen Arten der Untergattung Streptobacterium. Arch. Microbiol. 94:221-247.

11. Stetter, K. O., E. Lauer, and O. Kandler. 1978. Die Streptobakterienflora von Sauerkraut, p. 7. In Abstracts from the First Meeting of Section I "Allgemeine und Angewandte Mikrobiologie" of the German Society of Hygiene and Microbiology, Kiel, 12 to 13 April 1978. German Society of Hygiene and Microbiology, Kiel, Germany. 